\title{
PENGARUH FAKTOR AIR SEMEN TERHADAP SIFAT MEKANIK BETON RINGAN STYROFOAM
}

\author{
I.G.A. Neny Purnawirati \\ Dosen Teknik Sipil Politeknik Negeri Bali \\ E-mail : nenypurnawirati@pnb.ac.id/HP :085935159191
}

\begin{abstract}
ABSTRAK
Beton ringan adalah beton yang dibentuk dari campuran antara semen, air, agregat halus, agregat kasar dengan berat jenis ringan dan tambahan campuran lainnya yang dapat menambah kekuatan beton. Dalam penelitian ini digunakan bahan tambah berupa styrofoam yang menjadi alternatif pengganti material yang bersifat lebih ringan, kedap air, dan memiliki kekuatan yang cukup baik. Salah satu hasil dari pemanfaatan limbah batu apung dan styrofoam adalah beton ringan, yang baik digunakan pada daerah-daerah rawan gempa karena beban geser yang timbul kecil karena berat satuan dinding menjadi lebih ringan. Penelitian ini dilakukan secara eksperimental di Laboratorium Struktur dan Bahan Fakultas Teknik Universitas Mataram. Tahap awal penelitian berupa pemeriksaan bahan penyusun beton dan pengujian terhadap kuat tekan, modulus elastisitas dan kuat tarik belah beton. Dalam penelitian ini dibuat benda uji berupa silinder dengan diameter $15 \mathrm{~cm}$ dan tinggi $30 \mathrm{~cm}$ dengan kuat tekan rencana 6,89 MPa. Variasi Faktor Air Semen (FAS) yang digunakan 0,$4 ; 0,45 ; 0,5 ; 0,55 ; 0,6 ; 0,65$. Berdasarkan hasil pengujian diperoleh hasil kuat tekan maksimum adalah 7,869 MPa yaitu pada FAS 0,45 dan kuat tarik belah maksimum adalah $1,047 \mathrm{MPa}$ yaitu pada FAS 0,45. Sedangkan modulus elastisitas maksimum adalah $8561,649 \mathrm{MPa}$ yaitu pada FAS 0,45. Nilai kuat tekan yang diperoleh telah memenuhi persyaratan kuat tekan beton ringan struktural ringan SNI 03-3449-2002. Beton ringan styrofoam baik digunakan untuk pembuatan beton struktural ringan.
\end{abstract}

Kata Kunci : Beton ringan struktural, FAS, kuat tekan, kuat tarik, Styrofoam

\begin{abstract}
Lightweight concrete is concrete formed from a mixture of cement, water, fine aggregate, coarse aggregate with light specific gravity and other additives that can increase the strength of concrete. In this research, an added material is used in the form of styrofoam which is an alternative substitute for materials that are lighter, waterproof, and have good strength. One of the results of the utilization of pumice and styrofoam waste is lightweight concrete, which is good for use in earthquakeprone areas because the resulting shear load is small because the unit weight of the walls becomes lighter. This research was conducted experimentally at the Structure and Materials Laboratory of the Faculty of Engineering, Mataram University. The initial stage of the research was an examination of the constituent materials of the concrete and testing of the compressive strength, modulus of elasticity and tensile strength of the concrete. In this study, a test object was made in the form of a cylinder with a diameter of $15 \mathrm{~cm}$ and a height of $30 \mathrm{~cm}$ with a compressive strength of 6.89 MPa. The variation of the Cement Water Factor (FAS) used was 0.4; 0.45; 0.5; 0.55; 0.6; 0.65. Based on the test results, the maximum compressive strength
\end{abstract}


is 7,869 MPa which is at FAS 0.45 and the maximum split tensile strength is 1.047 $M P a$, which is at FAS 0.45. While the maximum modulus of elasticity is 8561.649 $M P a$, which is at FAS 0.45. The compressive strength value obtained has met the compressive strength requirements of light structural lightweight concrete SNI 033449-2002. Styrofoam lightweight concrete is good for making lightweight structural concrete.

Keywords: Structural lightweight concrete, FAS, compressive strength, tensile strength, styrofoam

\section{PENDAHULUAN}

Pada saat ini telah dilakukan penelitian tentang beton ringan yang dibuat dari campuran styrofoam. Penggunaan styrofoam dalam pembuatan beton ringan dapat dianggap sebagai rongga udara. Beton dengan styrofoam berat satuannya dapat dibuat hingga jauh lebih kecil dibandingkan dengan beton normal. Perancangan campuran beton perlu dilakukan untuk menentukan perbandingan campuran bahan guna mendapatkan beton dengan sifat yang diperlukan. Sifat yang diinginkan tergantung pada pembuatan beton. Sifat-sifat yang dapat diatur oleh perbandingan campuran adalah kekuatan ketahanan kedap air dan kemampuan pengerjaan. Air pada pembuatan adukan beton ringan berfungsi untuk mempermudah sifat pengerjaan beton atau meningkatkan kinerja (workability) beton ringan. Dalam kondisi tertentu seringkali kita dihadapkan pada suatu masalah penurunan kualitas beton, hal itu berkaitan dengan pemakaian jumlah air pada suatu campuran beton, yang lebih dikenal dengan Faktor Air Semen (FAS). Berdasarkan uraian diatas, maka dalam penelitian ini digunakan nilai Faktor Air Semen (FAS) yang berbeda pada masing-masing benda uji, penelitian ini juga menggunakan styrofoam sebagai bahan tambah. Diharapkan nantinya diperoleh beton ringan dengan kuat tekan yang memenuhi standar yang telah ditentukan untuk jenis beton ringan.

\section{TINJAUAN PUSTAKA}

FAS yang rendah menyebabkan air yang berada di antara bagian-bagian semen sedikit dan jarak antara butiran-butiran semen menjadi pendek. Akibatnya massa semen menunjukkan keterkaitannya (kekuatan awal lebih berpengaruh). Batuan semen mencapai kepadatan yang tinggi (normal ratio sekitar 0,25-0,65). Untuk bereaksi dengan semen, air yang diperlukan hanya sekitar $25 \%$ dari berat semen dan dengan menggunakan faktor air semen yang rendah tentu kuat tekan yang diperoleh akan tinggi dan sebaliknya. Namun kenyataannya pada suatu nilai tertentu digunakan nilai faktor air semen yang rendah tidak meningkatkan kuat tekan betonnya, hal ini disebabkan karena workability yang rendah atau atau adukan beton sulit dipadatkan (Mulyono, 2003).

Kuat tekan dinotasikan dengan $\mathrm{f}_{\mathrm{c}}$, yaitu tegangan tekan maksimum yang didapatkan melalui tata cara pengujian standar, menggunakan mesin uji CTM (Compression Testing Machine) dengan cara memberikan beban bertingkat dengan kecepatan peningkatan beban tertentu pada benda uji silinder sampai hancur (Dipohusodo, 1994). Tegangan tekan maksimum $\mathrm{f}_{\mathrm{c}}{ }_{\mathrm{c}}$ diberikan persamaan berikut : 


$$
\mathrm{f}^{\prime}{ }_{\mathrm{c}}=\frac{\mathrm{P}}{\mathrm{A}}
$$

dengan :

$$
\begin{aligned}
& \mathrm{f}^{\prime}{ }_{c}=\text { Kuat tekan }(\mathrm{MPa}) \\
& \mathrm{P}=\operatorname{Beban} \text { maksimum }(\mathrm{N}) \\
& \mathrm{A}=\text { Luas bidang maksimum }\left(\mathrm{mm}^{2}\right)
\end{aligned}
$$

Kuat tarik belah beton dalam analisa penampang balok biasanya diabaikan karena nilainya sangat kecil antara 10\% - 15\% dari kuat tekannya. Namun demikian kuat tarik ini memiliki pengaruh yang signifikan dalam perhitungan balok beton dalam kondisi layan (serviceability) yang biasanya ditentukan oleh perhitungan defleksinya. Karena kesulitan melakukan uji tarik beton dengan menggunakan metode langsung (direct unaxial tension), maka metode pengujian langsung ini tidak dijadikan sebagai standar pengujian (Neville and Brooks, 2003). Namun sebagai alternatif SNI 03-2491-1991 menyarankan untuk melakukan pengujian tarik beton dengan cara uji tarik tidak langsung yaitu uji lentur (flexural test). Dalam pengujian ini dilakukan pengujian tarik belah dengan silinder yang ukurannya sama dengan benda uji dalam percobaan tekan. Kuat tarik belah dihitung dengan rumus sebagai berikut :

$$
\mathrm{f}_{\mathrm{ct}}=\frac{2 \mathrm{P}}{\pi \mathrm{LD}}
$$

dengan :

$$
\begin{aligned}
& \mathrm{f}_{\mathrm{ct}}=\text { kuat tarik belah }\left(\mathrm{N} / \mathrm{mm}^{2}\right) \\
& \mathrm{P}=\text { beban maksimum }(\mathrm{N}) \\
& \mathrm{L}=\text { panjang silinder }(\mathrm{mm}) \\
& \mathrm{D}=\text { diameter silinder }(\mathrm{mm})
\end{aligned}
$$

Modulus elastisitas beton dapat diketahui dari grafik hubungan tegangan-regangan pada pengujian kuat tekan beton. Modulus elastisitas $\left(E_{c}\right)$ adalah rasio dari tegangan normal tarik atau tekan terhadap regangan yang bersangkutan di bawah batas proporsional material. Secara umum untuk mencari nilai modulus elastisitas eksperimen dapat menggunakan rumus :

$$
\mathrm{E}_{\mathrm{c}}=\frac{\left(s_{2-S_{1}}\right)}{\left(\varepsilon_{2-0,00005)}\right.}
$$

dengan : $\quad$ Ec $=$ modulus elastisitas beton $(\mathrm{MPa})$

$$
\begin{aligned}
& \mathrm{S}_{2}=\text { tegangan sebesar } 40 \% \text { tegangan ultimitnya }(\mathrm{MPa}) \\
& \mathrm{S}_{1}=\text { tegangan beton pada saat regangan mencapai } 0,00005(\mathrm{MPa}) \\
& \varepsilon_{2}=\text { regangan yang terjadi pada saat tegangan mencapai } \mathrm{S}_{2}
\end{aligned}
$$




\section{METODE PENELITIAN}

Tujuan dari perencanaan campuran beton (Mix Design) adalah untuk mengetahui komposisi atau proporsi bahan-bahan penyusun beton agar memenuhi persyaratan teknis dan ekonomis, menghasilkan proporsi campuran yang optimal dengan kekuatan maksimum. Kriteria utama dalam mix design beton adalah kekuatan tekan beton (hubungannya dengan faktor air semen) dan kemudahan pengerjaan (workability). Adapun kebutuhan benda uji untuk pengujian kuat tekan, kuat tarik belah, dan modulus elastisitas beton dalam penelitian ini dapat dlihat pada Tabel 3.1 berikut :

Tabel 1. Jumlah Kebutuhan Benda Uji

\begin{tabular}{|c|c|c|}
\hline \multirow{2}{*}{$\begin{array}{c}\text { Kode } \\
\text { benda uji }\end{array}$} & \multicolumn{2}{|c|}{ Jumlah benda uji } \\
\cline { 2 - 3 } & Modulus Elastisitas (silinder) & $\begin{array}{c}\text { Kuat tarik } \\
\text { (silinder) }\end{array}$ \\
\hline BRS040 & 5 & 5 \\
\hline BRS045 & 5 & 5 \\
\hline BRS050 & 5 & 5 \\
\hline BRS055 & 5 & 5 \\
\hline BRS060 & 5 & 5 \\
\hline BRS065 & 5 & 30 \\
\hline Total & 30 & 5 \\
\hline
\end{tabular}

dengan:

BRS040 = Beton ringan styrofoam dengan faktor air semen 0,40

BRS045 = Beton ringan styrofoam dengan faktor air semen 0,45

BRS050 $=$ Beton ringan styrofoam dengan faktor air semen 0,5

BRS055 = Beton ringan styrofoam dengan faktor air semen 0,55

BRS060 = Beton ringan styrofoam dengan faktor air semen 0,6

BRS065 = Beton ringan styrofoam dengan faktor air semen 0,65 
Adapun langkah-langkah dalam pembuatan benda uji berupa silinder adalah sebagai berikut :

1. Pengadaan styrofoam dalam bentuk granural dengan diameter $5 \mathrm{~mm}$.

2. Pengadaan material pasir, batu apung dan semen.

3. Mempersiapkan cetakan benda uji berupa silinder dengan ukuran $\mathrm{d}=150 \mathrm{~mm}$ dan $\mathrm{h}=300 \mathrm{~mm}$.

4. Menyiapkan dan menimbang bahan yang digunakan dengan proporsi yang telah ditentukan.

5. Setelah ditimbang bahan semen, styrofoam, batu apung, pasir diaduk hingga rata menggunakan sendok semen.

6. Menambahkan air, dimana dalam pengujian ini, digunakan faktor air semen yang berbeda, masing-masing 0,$4 ; 0,45 ; 0,5 ; 0,55 ; 0,6 ; 0,65$ sesuai dengan perbandingan berat air : berat semen.

7. Bahan yang telah dicampurkan kemudian dimasukkan ke dalam cetakan sesuai dengan cetakan benda uji silinder, dan tidak lupa ditusuk-tusuk dengan tongkat atau mesin pemadat untuk memadatkan benda uji.

8. Kemudian adonan dikeringkan untuk proses pengerasan. Metode yang digunakan pada proses pengerasan adalah secara alami (normal), yaitu 28 hari.

Pengujian kuat tekan berdasarkan SNI 03-2493-1991 dengan menggunakan alat Compression Testing Machine dengan langkah-langkah sebagai berikut :

1. Sebelum dilakukan pengujian terlebih dahulu benda uji diratakan permukaannya dengan

2. menggunakan semen atau belerang. Setelah ditimbang, benda uji diletakkan pada alat pembebanan mesin uji tekan beton (Compression Testing Machine).

3. Kemudian pembebanan diberikan secara berangsur-angsur sampai benda uji tersebut mencapai pembebanan maksimal. Besar beban dicatat sesuai jarum petunjuk pembebanan.

4. Beban yang mampu ditahan masing masing benda uji (P) dibagi dengan luas permukaan beton yang tekan (A), sehingga diperoleh kuat tekan beton maksimum tersebut. 


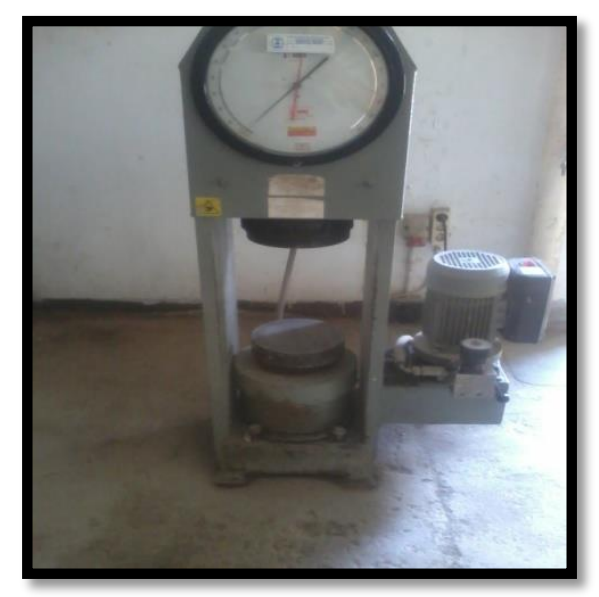

Gambar 1. Mesin uji tekan beton

Pengujian kuat tarik berdasarkan SNI 03-2493-1991 dengan menggunakan alat Compression Testing Machine dengan langkah-langkah sebagai berikut :

1. Gambar garis diameter pada kedua ujung silinder, yang satu sama lain sejajar dan kemudian membuat garis yang menghubungkan kedua ujung garis diameter tersebut. Periksa apakah kedua garis sejajar dengan sumbu silinder tersebut berada benar-benar pada kedua sisinya.

2. Ukur diameter silinder sampai ketelitian $0,2 \mathrm{~mm}$. Pengukuran dilakukan pada dekat kedua ujung silinder dan ditengah-tengah silinder dengan arah pengukuran sama dengan arah pembebanan. Dari hasil pengukuran silinder, diambil rata-ratnya.

3. Ukur panjang silinder sampai ketelitian $2 \mathrm{~mm}$. Pengukuran diambil rata-rata dari hasil pengukuran panjang silinder pada kedua sisi yang menempel pada blok tekan mesinnya.

4. Taruh plat tipis kayu di atas blok mesin tekan yang di bawah dengan melalui pusat diameter bloknya.

5. Taruh benda uji silinder di atas plat tipis kayu, dengan garis diameter vertikal. Perhatikan silinder telah benar-benar terletak semuanya di atas plat tipis kayu.

6. Taruh plat tipis kayu yang satunya di atas silinder beton

7. Periksa sekali lagi, apakah kedudukan silinder beton telah berada diantara dua blok mesin secara sentris dan semua plat tipis kayu berada sejajar dengan sumbu silinder

8. Terapkan beban pada silinder secara terus menerus dan tidak boleh secara mendadak. Kecepatan pembebanan dibuat antara $50 \mathrm{KN}$ dan $100 \mathrm{KN}$ tiap menit. Pembebanan dilakukan sampai beton tersebut pecah. 


\section{HASIL DAN PEMBAHASAN}

Nilai kuat tekan silinder yang dipergunakan adalah nilai kuat tekan yang diperoleh dari hasil uji tekan silinder pada usia 28 hari. Dari hasil uji tekan silinder, diperoleh nilai beban maksimum rata-rata seperti yang ditunjukkan oleh Tabel 2 .

Tabel 2. Nilai beban $(\mathrm{P})$ rata-rata silinder

\begin{tabular}{|c|c|c|c|c|c|c|}
\hline NO & BRS04 & BRS045 & BRS05 & BRS055 & BRS06 & BRS065 \\
\hline 1 & 85 & 150 & 130 & 115 & 125 & 145 \\
\hline 2 & 85 & 135 & 145 & 110 & 120 & 145 \\
\hline 3 & 85 & 135 & 145 & 120 & 120 & 145 \\
\hline 4 & 80 & 135 & 115 & 130 & 140 & 120 \\
\hline 5 & 105 & 130 & 125 & 130 & 125 & 140 \\
\hline $\begin{array}{c}\text { Rata- } \\
\text { rata }\end{array}$ & $88 \mathrm{KN}$ & $137 \mathrm{KN}$ & $132 \mathrm{KN}$ & $121 \mathrm{KN}$ & $126 \mathrm{KN}$ & $139 \mathrm{KN}$ \\
\hline $\begin{array}{c}\text { Rata- } \\
\text { rata }\end{array}$ & $88000 \mathrm{~N}$ & $137000 \mathrm{~N}$ & $132000 \mathrm{~N}$ & $121000 \mathrm{~N}$ & $126000 \mathrm{~N}$ & $139000 \mathrm{~N}$ \\
\hline
\end{tabular}

Berdasarkan tabel 2, terlihat untuk beton ringan styrofoam dengan faktor air semen (FAS) 0,4 memiliki beban (p) sebesar $85 \mathrm{KN}, 85 \mathrm{KN}, 85 \mathrm{KN}, 80 \mathrm{KN}$, dan $105 \mathrm{KN}$ dengan nilai rata-ratanya $88 \mathrm{KN}$. Setelah melalui perhitungan uji tekan silinder didapatkan nilai kuat tekan rata-rata untuk faktor air semen (FAS) 0,4 adalah 4,982 $\mathrm{MPa}$. Untuk beton ringan styrofoam dengan faktor air semen (FAS) 0,45 memiliki beban (p) sebesar $150 \mathrm{KN}, 135 \mathrm{KN}, 135 \mathrm{KN}, 135 \mathrm{KN}, 130 \mathrm{KN}$ dengan nilai rataratanya $137 \mathrm{KN}$. Setelah melalui perhitungan uji tekan silinder didapatkan nilai kuat tekan rata-rata untuk faktor air semen (FAS) 0,45 adalah 7,756 MPa. Untuk beton ringan styrofoam dengan faktor air semen (FAS) 0,5 memiliki beban (p) sebesar $130 \mathrm{KN}, 145 \mathrm{KN}, 145 \mathrm{KN}, 115 \mathrm{KN}, 125 \mathrm{KN}$ dengan nilai rata-ratnya $132 \mathrm{KN}$. Setelah melalui perhitungan uji tekan silinder didapatkan nilai kuat tekan rata-rata untuk faktor air semen (FAS) 0,5 adalah 7,473 MPa. Untuk beton ringan styrofoam dengan faktor air semen (FAS) 0,55 memiliki beban (p) sebesar $115 \mathrm{KN}, 110 \mathrm{KN}$, $120 \mathrm{KN}, 130 \mathrm{KN}, 130 \mathrm{KN}$ dengan nilai rata-ratanya $121 \mathrm{KN}$. Setelah melalui perhitungan uji tekan silinder didapatkan nilai kuat tekan rata-rata untuk faktor air semen (FAS) 0,55 adalah 6,850 MPa. Untuk beton ringan styrofoam dengan faktor air semen (FAS) 0,6 memiliki beban (p) sebesar $125 \mathrm{KN}, 120 \mathrm{KN}, 120 \mathrm{KN}, 140$ $\mathrm{KN}, 125 \mathrm{KN}$ dengan nilai rata-ratanya $126 \mathrm{KN}$. Setelah melalui perhitungan uji tekan silinder didapatkan nilai kuat tekan rata-rata untuk faktor air semen (FAS) 0,6 adalah 7,133 MPa. Untuk beton ringan styrofoam dengan faktor air semen (FAS) 0,65 memiliki beban (p) sebesar $145 \mathrm{KN}, 145 \mathrm{KN}, 145 \mathrm{KN}, 120 \mathrm{KN}, 140 \mathrm{KN}$ dengan nilai rata-ratanya $139 \mathrm{KN}$. Setelah melalui perhitungan uji tekan silinder didapatkan nilai kuat tekan rata-rata untuk faktor air semen (FAS) 0,65 adalah 7,869 $\mathrm{MPa}$ 


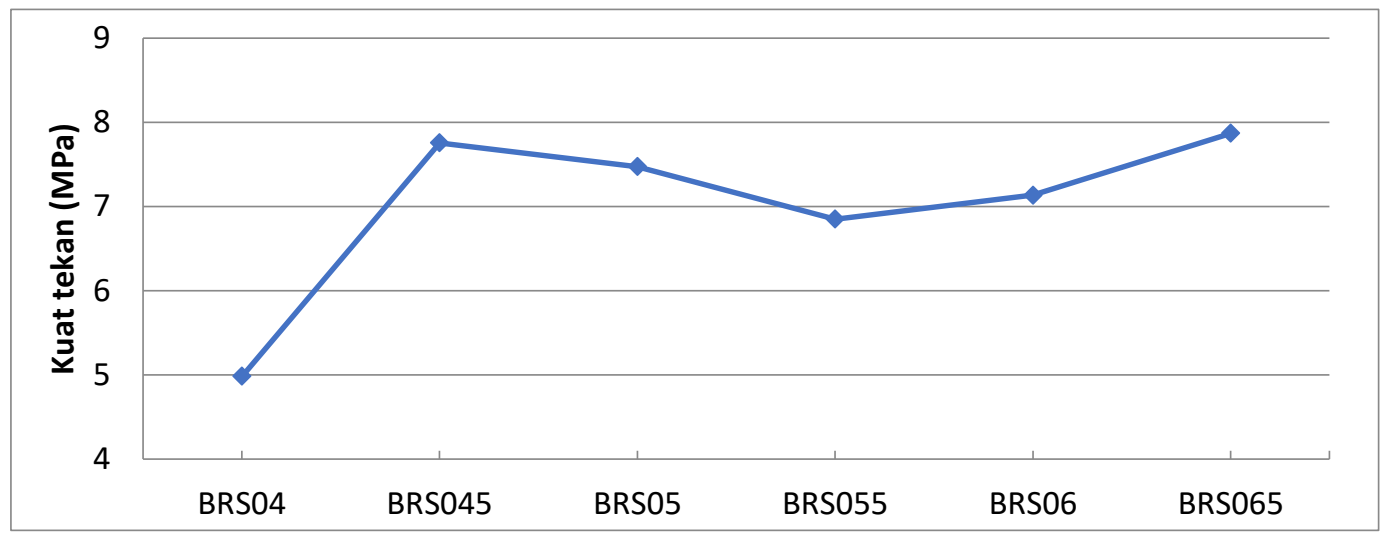

Gambar 2. Grafik Kuat Tekan Beton Ringan Styrofoam dengan variasi FAS

Dari Gambar 2 tertera nilai kuat tekan dari masing-masing silinder. Nilai kuat tekan tersebut dapat dihitung dengan menggunakan persamaan (2-2). Nilai kuat tekan yang diperoleh dari hasil pengujian sudah memenuhi syarat standar kuat tekan beton ringan struktural yang direncanakan pada umur 28 hari yaitu sebesar 6,89 MPa. Untuk beton ringan dengan FAS 0,4 tidak memenuhi standar kuat tekan beton ringan struktural, karena nilai kuat tekan yang didapat tidak memenuhi standar yang direncanakan. Dari gambar diatas dapat dilihat bahwa nilai kuat tekan maksimum terjadi pada beton ringan dengan FAS 0,4 dan FAS 0,65, dan nilai kuat tekan mengalami penurunan pada FAS 0,55. Dari hasil uji kuat tarik silinder, diperoleh beban maksimum rata-rata seperti yang ditunjukkan pada tabel 4.8 berikut :

Tabel 3. Nilai beban $(\mathrm{P})$ rata-rata pada silinder

\begin{tabular}{|c|c|c|c|c|c|c|}
\hline NO & BRS04 & BRS045 & BRS05 & BRS055 & BRS06 & BRS065 \\
\hline 1 & 40 & 65 & 70 & 65 & 60 & 75 \\
\hline 2 & 45 & 70 & 65 & 70 & 65 & 85 \\
\hline 3 & 40 & 65 & 75 & 65 & 70 & 75 \\
\hline 4 & 50 & 70 & 65 & 65 & 65 & 75 \\
\hline 5 & 35 & 75 & 70 & 70 & 65 & 60 \\
\hline $\begin{array}{c}\text { Rata- } \\
\text { rata }\end{array}$ & $42 \mathrm{KN}$ & $69 \mathrm{KN}$ & $69 \mathrm{KN}$ & $67 \mathrm{KN}$ & $65 \mathrm{KN}$ & $74 \mathrm{KN}$ \\
\hline $\begin{array}{c}\text { Rata- } \\
\text { rata }\end{array}$ & $42000 \mathrm{~N}$ & $69000 \mathrm{~N}$ & $69000 \mathrm{~N}$ & $67000 \mathrm{~N}$ & $65000 \mathrm{~N}$ & $74000 \mathrm{~N}$ \\
\hline
\end{tabular}

Berdasarkan tabel 4.8 terlihat untuk beton ringan styrofoam dengan faktor air semen (FAS) 0,4 memiliki beban (p) sebesar $40 \mathrm{KN}, 45 \mathrm{KN}, 40 \mathrm{KN}, 50 \mathrm{KN}, 35$ $\mathrm{KN}$ dengan nilai rata-ratanya $42 \mathrm{KN}$. Setelah melalui perhitungan uji tarik-belah 
silinder didapatkan nilai kuat tarik-belah rata-rata untuk faktor air semen (FAS) 0,4 adalah 0,594 MPa. Untuk beton ringan styrofoam dengan faktor air semen (FAS) 0,45 memiliki beban (p) sebesar $65 \mathrm{KN}, 70 \mathrm{KN}, 65 \mathrm{KN}, 70 \mathrm{KN}, 75 \mathrm{KN}$ dengan nilai rata-ratanya $69 \mathrm{KN}$. Setelah melalui perhitungan uji tarik-belah silinder didapatkan nilai kuat tarik-belah rata-rata untuk faktor air semen (FAS) 0,45 adalah 0,976 $\mathrm{MPa}$. Untuk beton ringan styrofoam dengan faktor air semen (FAS) 0,5 memiliki beban (p) sebesar $70 \mathrm{KN}, 65 \mathrm{KN}, 75 \mathrm{KN}, 65 \mathrm{KN}, 70 \mathrm{KN}$ dengan nilai rata-ratanya $69 \mathrm{KN}$. Setelah melalui perhitungan uji tarik-belah silinder didapatkan nilai kuat tarik-belah rata-rata untuk faktor air semen (FAS) 0,5 adalah $0,976 \mathrm{MPa}$. Untuk beton ringan styrofoam dengan faktor air semen (FAS) 0,55 memiliki beban (p) sebesar $65 \mathrm{KN}, 70 \mathrm{KN}, 65 \mathrm{KN}, 65 \mathrm{KN}, 70 \mathrm{KN}$ dengan nilai rata-ratanya $67 \mathrm{KN}$. Setelah melalui perhitungan uji tarik-belah silinder didapatkan nilai kuat tarik-belah rata-rata untuk faktor air semen (FAS) 0,55 adalah $0,948 \mathrm{MPa}$. Untuk beton ringan styrofoam dengan faktor air semen (FAS) 0,6 memiliki beban (p) sebesar $60 \mathrm{KN}, 65 \mathrm{KN}, 70 \mathrm{KN}, 65 \mathrm{KN}, 65 \mathrm{KN}$ dengan nilai rata-ratanya $65 \mathrm{KN}$. Setelah melalui perhitungan uji tarik-belah silinder didapatkan nilai kuat tarik-belah rata-rata untuk faktor air semen (FAS) 0,6 adalah $0,920 \mathrm{MPa}$. Untuk beton ringan styrofoam dengan faktor air semen (FAS) 0,65 memiliki beban (p) sebesar $75 \mathrm{KN}, 85 \mathrm{KN}, 75 \mathrm{KN}, 75 \mathrm{KN}, 60 \mathrm{KN}$ dengan nilai rata-ratanya $74 \mathrm{KN}$. Setelah melalui perhitungan uji tarik-belah silinder didapatkan nilai kuat tarik-belah rata-rata untuk faktor air semen (FAS) 0,65 adalah $1,047 \mathrm{MPa}$.

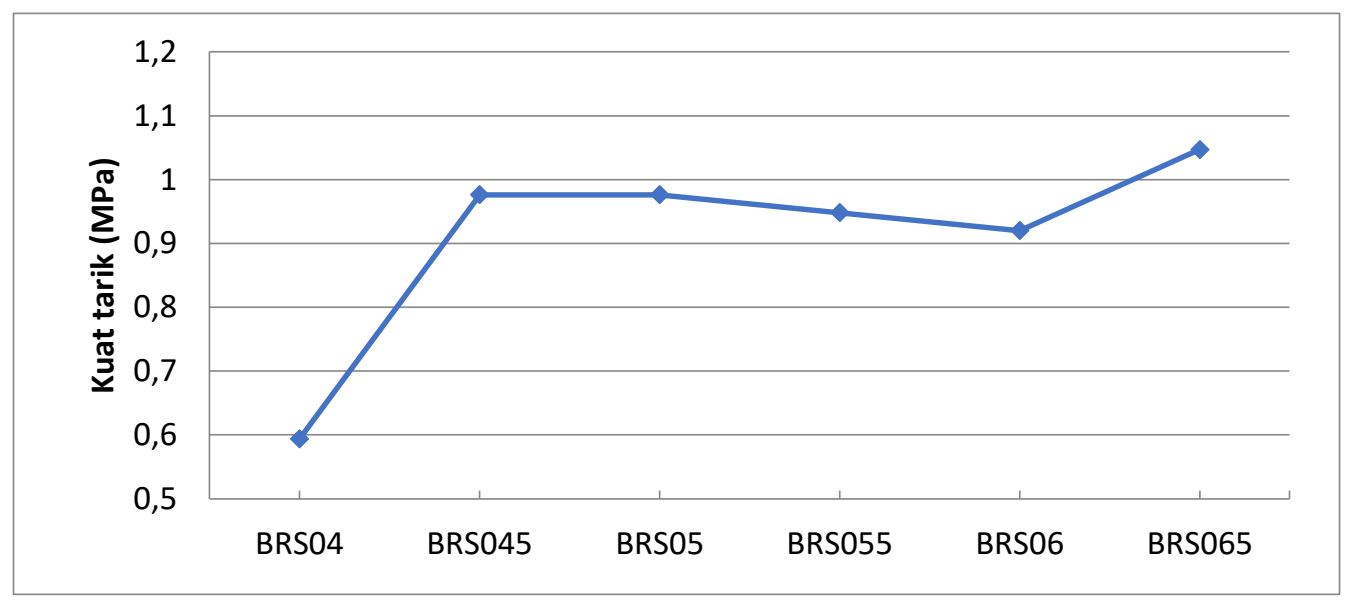

Gambar 3. Grafik Kuat Tarik Beton Ringan Styrofoam dengan variasi FAS

Pada Gambar 2 diatas, nilai kuat tarik meningkat pada FAS 0,45 dan mengalami penurunan pada FAS 0,55 dan 0,6 dan meningkat kembali pada FAS 0,65. Nilai kuat tarik belah beton ini sudah memenuhi syarat yang telah ditentukan yaitu memenuhi yaitu memenuhi kuat tari belah sebesar (8 - 15\%) dari kuat tekannya (Asroni, A. 2010). Penurunan ini kemungkinan disebabkan oleh beban yang mampu diterima oleh beton sangat kecil, dan nilai FAS yang kecil mempengaruhi besarnya beban yang mampu diterima oleh beton.

Hasil pengujian modulus elastisitas beton dengan menggunakan mesin uji tekan Compression Testing Machine (CTM) dilakukan dengan menghitung besarnya 
pemendekan beton (benda uji) dalam arah vertikal secara simetris akibat pemberian beban secara terus menerus. Hasil pengujian nilai modulus elastisitas dapat dilihat pada tabel di bawah ini.

Tabel 4. Nilai modulus elastisitas beton ringan

\begin{tabular}{|c|c|c|c|c|c|c|}
\hline NO & $\begin{array}{c}\text { BRS04 } \\
(\mathrm{MPa})\end{array}$ & $\begin{array}{c}\text { BRS045 } \\
(\mathrm{MPa})\end{array}$ & $\begin{array}{c}\text { BRS05 } \\
(\mathrm{MPa})\end{array}$ & $\begin{array}{c}\text { BRS055 } \\
(\mathrm{MPa})\end{array}$ & $\begin{array}{c}\text { BRS06 } \\
(\mathrm{MPa})\end{array}$ & $\begin{array}{c}\text { BRS065 } \\
(\mathrm{MPa})\end{array}$ \\
\hline 1 & 1534,482 & 1817,679 & 2661,993 & 2164,201 & 1521,907 & 2120,950 \\
\hline 2 & 1133,448 & 2244,389 & 1910,658 & 2332,173 & 1504,210 & 2162,337 \\
\hline 3 & 1398,181 & 2290,520 & 1850,467 & 1690,972 & 1242,677 & 1723,628 \\
\hline 4 & 845,517 & 2392,717 & 2213,808 & 1442,080 & 1376,053 & 1969,111 \\
\hline 5 & 970,921 & 2573,248 & 2053,278 & 1732,217 & 1556,325 & 1794,228 \\
\hline
\end{tabular}

Nilai modulus elastisitas diperoleh dari grafik hubungan tegangan regangan dalam masing-masing silinder yang nantinya setelah diplotkan akan mendapatkan sebuah persamaan. Dari persamaan tersebut kita bisa memperoleh nilai modulus elastisitas masing-masing benda uji. Untuk perhitungan mengenai modulus elastisitas selengkapnya dapat diihat pada lampiran II. Dari tabel di atas mengenai nilai modulus elastisitas beton ringan styrofoam untuk benda uji dengan FAS 0,4 dengan 5 buah sampel masing-masing nilai modulus elastisitas sebesar 1534,482 MPa, 1133,448 MPa, 1398,181 MPa, 845,517 MPa, 970,921 MPa, disini terlihat nilai modulus elastisitas semakin menurun hal ini disebabkan karena nilai perpendekan beban semakin besar, terlihat dari tabel uji tekan silinder untuk faktor air semen 0,4 nilai perpendekan beban masing-masing sampel semakin bertambah. Untuk nilai modulus elastisitas beton ringan styrofoam dengan FAS 0,45 dengan 5 buah sampel masing-masing nilai modulus elastisitas sebesar 1817,679 MPa, 2244,389 MPa, 2290,520 MPa, 2392,717 MPa, 2573,248 MPa, disini terlihat nilai modulus elastisitas semakin bertambah hal ini disebabkan karena nilai perpendekan beban semakin kecil, terlihat dari tabel benda uji tekan silinder untuk faktor air semen 0,45 nilai perpendekan beban masing-masing sampel semakin berkurang. Untuk nilai modulus elastisitas beton ringan styrofoam dengan FAS 0,5 dengan 5 buah sampel masing-masing nilai modulus elastisitas sebesar 2661,993 MPa, 1910,658 MPa, 1850,467 MPa, 2213,808 MPa, 2053,278 MPa, disini terlihat bahwa nilai modulus elastisitas untuk 5 sampel ini ada yang mengalami peningkatan dan ada juga yang mengalami penurunan. Untuk nilai modulus elastisitas beton ringan styrofoam dengan FAS 0,55 dengan 5 buah sampel masing-masing nilai modulus elastisitas sebesar 2164,201 MPa, 2332,173 $\mathrm{MPa}, 1690,972 \mathrm{MPa}, 1442,080 \mathrm{MPa}, 1732,217 \mathrm{MPa}$, disini terlihat bahwa nilai modulus elastisitas 2 sampel mengalami peningkatan dan dan sisanya mengalami penurunan. Untuk nilai modulus elastisitas beton ringan styrofoam dengan FAS 0,6 dengan 5 buah sampel masing-masing nilai modulus elastisitas sebesar 1521, $907 \mathrm{MPa}, 1504,210 \mathrm{MPa}, 1242,677 \mathrm{MPa}, 1376,053 \mathrm{MPa}, 1556,325 \mathrm{MPa}$, disini 
terlihat 4 buah sampel mengalami penurunan nilai modulus elastisitas hal ini disebabkan karena adanya peningkatan nilai perpendekan beban. Untuk nilai modulus elastisitas beton ringan styrofoam dengan FAS 0,65 dengan 5 buah sampel masing-masing nilai modulus elastisitas sebesar 2120,950 MPa, 2162,337 MPa, 1723,628 MPa, 1969,111 MPa, 1794,228 MPa.

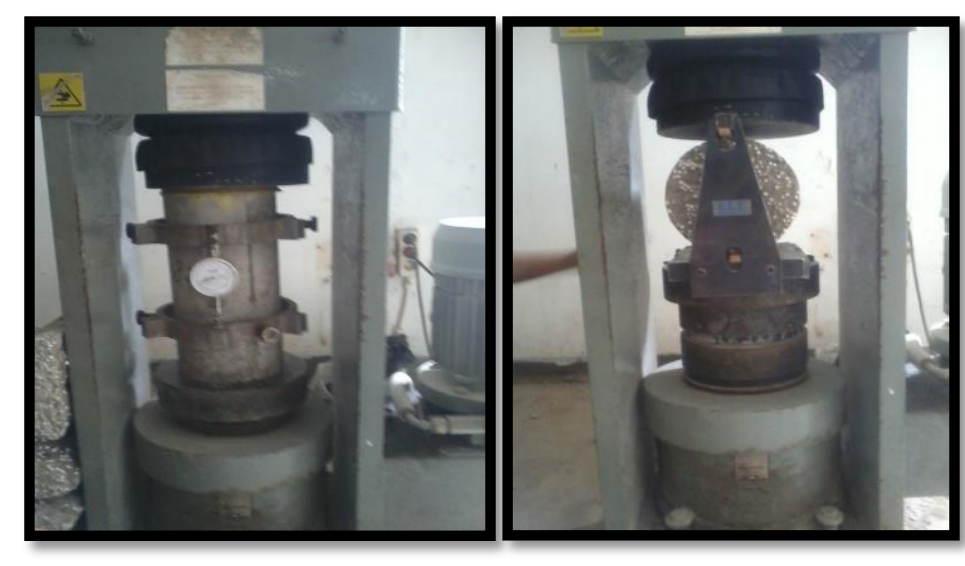

1. Pengujian kuat tekan
2. Pengujian kuat tarik belah

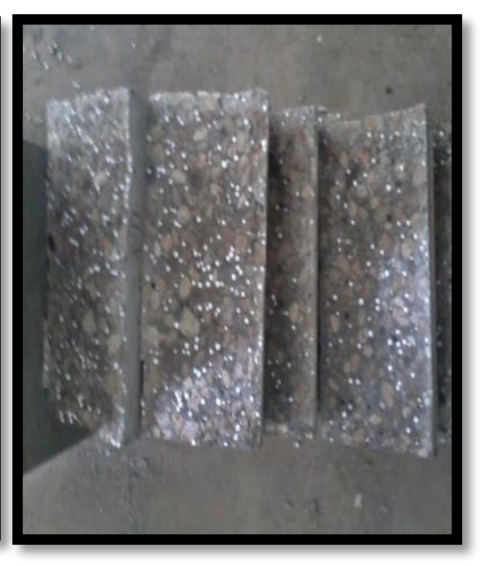

3. Hasil pengujian

\section{PENUTUP}

Dari keenam variasi Faktor Air Semen (FAS) yang digunakan, hanya 5 nilai FAS yang memenuhi standar nilai kuat tekan beton ringan yakni, 0,$45 ; 0,5 ; 0,55 ; 0,6$; 0,65. Sedangkan nilai FAS 0,4 tidak memenuhi standar kuat tekan beton ringan karena nilainya kurang dari 6,89 MPa.

1. Untuk pengujian modulus elastisitas, nilai FAS 0,4 memiliki nilai modulus elastisitas yang sangat kecil, ini disebabkan karena pada pengujian tekan nilai FAS 0,4 mendapatkan beban yang kecil dibandingkan dengan FAS lainnya.

2. Untuk pengujian kuat tarik, nilai FAS 0,4 memiliki nilai kuat tarik yang kecil dibandingkan dengan nilai FAS lainnya.

3. FAS optimum pada penelitian ini adalah FAS 0,$45 ; 0,5 ; 0,65$ karena memberikan nilai kuat tekan yang tinggi dibandingkan dengan nilai kuat tekan pada FAS lainnya, akan tetapi jika dilihat dari berat beton ringan, nilai FAS 0,45 merupakan yang paling optimum, karena selain memiliki nilai kuat tekan yang tinggi, juga memiliki berat yang ringan dibandingkan dengan 3 FAS optimum yang lainnya.

4. Sebaiknya styrofoam dituangkan paling terakhir, pada saat adonan mulai tercampur rata. Jika styrofoam dituangkan pada saat bersamaan dengan pasir dan semen, maka styrofoam tidak dapat menyatu, sehingga menjadi gumpalangumpalan bahkan tidak ikut tercampur dengan pasta.

5. Untuk penelitian selanjutnya, diharapkan dapat merencanakan kuat tekan dengan nilai kuat tekan yang lebih tinggi, agar mendapatkan beton ringan dengan nilai kuat tekan yang cukup tinggi.

6. Dalam penelitian selanjutnya, dapat menambahkan serat, yang dapat meningkatkan nilai kuat tarik pada beton ringan. 


\section{DAFTAR PUSTAKA}

1. Anonim, 2002, SK SNI-03-3449-2002, Tata Cara Perancangan Campuran Beton Ringan Dengan Agregat Ringan, Badan Standar Nasional (BSN), Jakarta.

2. Asroni, A., 2010, Balok dan Pelat Beton Bertulang, Edisi Pertama, Jilid 1, Graha Ilmu, Surakarta.

3. Dipohusoodo, I., 1994, Struktur Beton Bertulang, Berdasarkan SK SNI T-151991-03, DPU, Gramedia, Jakarta.

4. Mulyono, T. 2003. Teknologi Beton. Yogyakarta : Andi Offset. 